\title{
FACTORS THAT INFLUENCE THE SUCCESS OF CONCEPTUAL CHANGE MODEL (CCM) ON COURSE LEARNING OF MATHEMATICS ELEMENTARY
}

\author{
Rina Wijayanti, Dyah Ayu Sulistyaning Cipta \\ Mathematics Education, Institute of Teacher Education and Educational Science of Budi Utomo \\ Malang \\ Jl. Citandui no.46, Malang, \\ rina.statistika12@gmail.com,dyahayu.esce@gmail.com
}

\begin{abstract}
The Course of Mathematics Elementary School is a course intended to prepare university students to become a math teacher in elementary school. The material in Mathematics Study of Elementary School is Integer and Fractional. This case study get in Institute of Teacher Education and Educational Science of Budi Utomo Malang. The author teach this material with the Conceptual Change Model. Next we want to know the factors that affect Conceptual Change Model. The sample was taken from 45 students of Mathematics Education and obtained the conclusion of Process of conceptual changes variable, Cognitive Conflict and Knowledge of the past have significant effect on CCM success in elementary mathematics study, it is proved from the value of $\mathrm{p}$ value of the three consecutive variables $(0.00$; $0.001 ; 0.034)$ these three values are $<0.05$ ( $5 \%$ error rate / alpha).

Keywords: CCM, Course of Mathematics Elementary School
\end{abstract}

\section{INTRODUCTION}

Learning in the classroom is boring for students. That situations are less conducive to The Course of Mathematics Elementary School is a course intended to prepare students to become a math teacher in elementary school. One of the most fundamental things that must be mastered for students is the mastery of mature concepts. The concept of mathematics according to Hudojo is an abstract idea that allows us to classify objects and events and to classify whether the objects and events are included or not into the abstract idea (Hudoyo, 2013).

In the Learning of Integer, none of the students of class 2014 F Institute of Teacher Education and Educational Science of Budi Utomo Malang are able to explain conceptually, from which they get the answer from the result of multiplication of two integers. They can only answer that $-2 \times 3$ yields -6 , without knowing where they got -6 . All they know is that if negative is multiplied positive it will give negative result. The answer is not wrong, but it feels so apprehensive if as a student of mathematics education course who will become a teacher of mathematics does not understand the concept of mathematics correctly. If this continues to be allowed to continue, then the learning of mathematics will only stop at the mere reconnaissance of a theory without a logic. 
After further investigation by conducting an investigation to 45 students of the class, it was found that 26 students among them never thought that it should be questioned. A total of 12 students admitted to getting information that a negative integer multiplied by a positive integer and produces a negative integer is a postulate of unquestioned origin. Then as many as 7 students claimed to have been digging the information but until now has not got the answer.

The lessons they have learned from elementary to high school, integer and fractional operations are always presented by stuffing the mathematical formulas without explaining where the formula came from. For example, when dealing with the reduction of negative numbers, $a-(-b)$, the teacher immediately assures students that

$$
a-(-b)=a+b
$$

Similarly, the fractions

$$
\frac{a}{b}: \frac{c}{d}
$$

The result is

$$
\frac{a}{b}: \frac{c}{d}=\frac{a}{b} x \frac{d}{c}
$$

Without any explanation as to why, without understanding the concept of reducing negative numbers, without understanding the concept of fractional division, they were asked to memorize the mathematical formulations.

The concept of numbers they should have had since the fourth grade of elementary school, then that means it has been for nearly ten years that the unfounded rules of the concept are so deeply rooted in their brains. After so long the rules are rooted, not an easy matter to fix them. So to correct the error of the concept, the author promises this round and fractional learning with the Conceptual Change Model. Yudistia mentions Conceptual Change Model is a teaching model that is based on student conception and can be applied by the teacher to straighten out student conception which is less clear or very different from scientific concept and at the same time build new conception (Yudistira, 2013).

Furthermore, for learning with Conceptual Change Model can be done maximally, writer do research to know factors influencing success of Conceptual Change Model by using Multiple Regression Analysis. Multiple regression is the appropriate method of analysis when the problem involves a single metric independent variable. The objective of multiple regression analysis is to predict the change in the dependent variable in response to the changes in several independent variables (Hair, 1995). 


\section{Methodology of Analysis}

\section{Data Source}

The sample data used in this research are 45 university students of Institute of Teacher Education and Educational Science of Budi Utomo Malang Mathematics Education as sample. The population in this study is a student of Mathematics Education IBUM.

\section{Research Variable}

Variable used in this research is

Tabel 1 Research Variable

\begin{tabular}{|c|c|}
\hline Variabel & Keterangan \\
\hline$Y$ & $\begin{array}{l}\text { Student Value for Elementary Mathematics Study Course with teach this } \\
\text { material with the Conceptual Change Model }\end{array}$ \\
\hline$X_{1}$ & $\begin{array}{l}\text { Process of conceptual changes } \\
1 \text { = Dissatisfied } \\
\text { learners are not satisfied with the concept they have (existing conception) in } \\
\text { explaining the information or data it knows } \\
2 \text { = Intelligible } \\
\text { new conceptions known to learners can be understood and build understanding } \\
3=\text { Plausible } \\
\text { learners must feel that the new concepts are reasonable, meaning that } \\
\text { knowledge is not only to build understanding and understandable, but must be a } \\
\text { belief (be believable) } \\
4=\text { Fruitful } \\
\text { learners must find that new concepts are beneficial and contribute to building } \\
\text { new insights and further hypotheses. Based on the above description MPPK } \\
\text { model is expected to improve students' conceptual understanding }\end{array}$ \\
\hline$X_{2}$ & Cognitive Conflict \\
\hline$X_{3}$ & Knowledge of the past $(1=$ no, $2=$ yes $)$ \\
\hline
\end{tabular}

\section{Discussion}

Conceptual change model was first submitted by Posner et al on 1982. It has been developed by Hewson and Hewson (1983, 1984), Strike dan Posner (1985, 1992), serta Thorley (1990). CCM has related with Knowledge of the past, experience and metacognitive ability (Barlia, 2009) (Funia, 2013). Author use three variable to know factors influencing success of Conceptual Change Model, the variable is Process of conceptual changes, Cognitive Conflict and Knowledge of the past.

Tabel 2 Descriptive Statistics

\begin{tabular}{llll}
\hline \multicolumn{1}{c}{ Variable } & Mean & Standard Deviation & $\mathrm{N}$ \\
\hline Student Value $(\mathrm{Y})$ & 70,22 & 19,62 & 45 \\
\hline Cognitive Conflict $\left(\mathrm{X}_{2}\right)$ & 70,89 & 11,04 & 45 \\
\hline
\end{tabular}


Based on table 1, the mean of student score is 70,22 with standard deviation 19,62 and the mean of Cognitive Conflict is 70,89

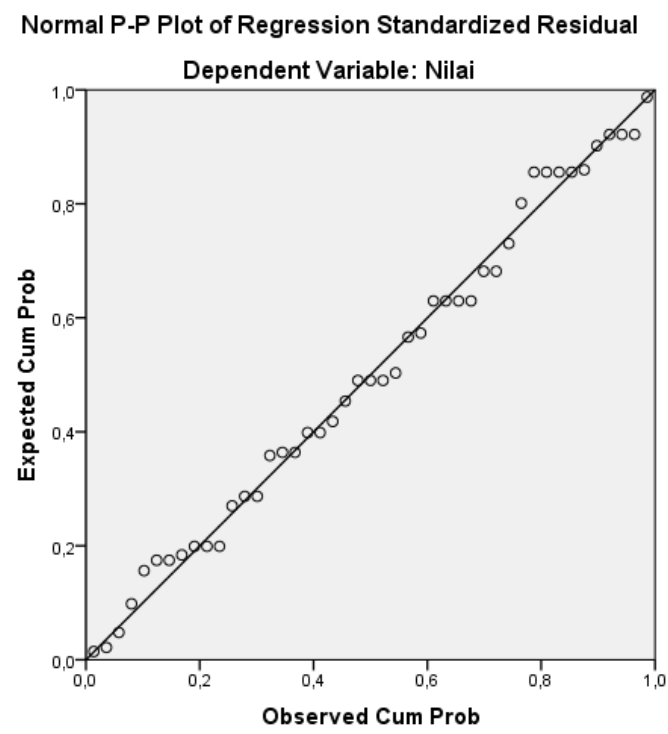

Fig 1 Normal P-P Plot

In the Regression Analysis assumption that must be fulfilled is the residual of normal distribution. Figure 1 is a normal P-P Plot of residuals that can be used for examination of residual normality. If the residual scattering around a straight line means the residual is normally distributed. In Figure 1, the residual is in a straight line so it can be concluded that the residual is normally distributed.

Tabel 3 Regression Model

\begin{tabular}{|c|c|c|c|c|c|c|c|c|c|c|}
\hline \multirow[t]{2}{*}{ Model } & \multirow[t]{2}{*}{$\mathrm{R}$} & \multirow{2}{*}{$\begin{array}{c}\mathrm{R} \\
\text { Square }\end{array}$} & \multirow{2}{*}{$\begin{array}{l}\text { Adjusted } \\
\text { R Square }\end{array}$} & \multirow{2}{*}{$\begin{array}{l}\text { Std. Error } \\
\text { of the } \\
\text { Estimate }\end{array}$} & \multicolumn{5}{|c|}{ Change Statistics } & \multirow{2}{*}{$\begin{array}{l}\text { Durbin- } \\
\text { Watson }\end{array}$} \\
\hline & & & & & $\begin{array}{l}\text { R Square } \\
\text { Change }\end{array}$ & $\begin{array}{c}\text { F } \\
\text { Change }\end{array}$ & df1 & df 2 & $\begin{array}{l}\text { Sig. F } \\
\text { Change }\end{array}$ & \\
\hline 1 & $0,862^{\mathrm{a}}$ & 0,743 & 0,737 & 10,06055 & 0,743 & 124,444 & 1 & 43 & 0,000 & \\
\hline 2 & $0,897^{\mathrm{b}}$ & 0,805 & 0,795 & 8,87646 & 0,062 & 13,237 & 1 & 42 & 0,001 & \\
\hline 3 & $0,908^{\mathrm{c}}$ & 0,825 & 0,812 & 8,50136 & 0,020 & 4,788 & 1 & 41 & 0,034 & 2,109 \\
\hline \multicolumn{11}{|c|}{ a. Predictors: (Constant), $\mathrm{X}_{1}$} \\
\hline \multicolumn{11}{|c|}{ b. Predictors: (Constant), $\mathrm{X}_{1}, \mathrm{X}_{2}$} \\
\hline \multicolumn{11}{|c|}{ c. Predictors: (Constant), $X_{1}, X_{2}$ dan $X_{3}$} \\
\hline
\end{tabular}

The second assumption test that must be fulfilled in regression analysis is independence of residual or absence of autocorrelation which can be seen from Durbin 
Watson value. Based on Table 3 Durbin Watson value of 2.109 then tested Hypothesis below

Hypothesis:

H0: $\rho=0$ means there is no positive or negative autocorrelation

H1: $\rho \neq 0$ means there is positive or negative autocorrelation

Critical Area: Failed to reject H0 when Durbin Watson du<d<4-du (Gujarati, 1995).

Based on Table 2 the $\mathrm{d}$ value is 2,109 , du is obtained from the Durbin Watson table $(\mathrm{n}=45, \mathrm{k}=3) \mathrm{du}=1.67$. So that obtained $1.67<2.109<2.33$ so that the conclusion failed to reject $\mathrm{H} 0$ means there is no positive or negative autocorrelation (assumption fulfilled). Regression Analysis Model used by the writer is the 3rd model with the highest R-square that is $82,5 \%$. The regression equation model obtained is

$$
Y=-27,367+9,227 X 1+0,697 \times 2+10,926 X 3
$$

The three variables X1, X2 and X3 have a significant effect on the success of CCM in the course of mathematics elementary school, it is evident from the value of $p$ value of the three variables in a row $(0.00,0.001,0.034)$ these three values $<0.05$ (5\% error rate / alpha).

\section{Conclution}

The success of Conceptual Change Model in Course of Mathematics Elementary School is influenced by Achievement of CCM, Cognitive Conflict and Knowledge of the past, it is proved from the value of $\mathrm{p}$ value of the three variables respectively $(0.00,0.001$, $0.034)$ these three values $<0.05$ (5\% error rate / alpha). Regression analysis model is obtained as follows

$$
Y=-27,367+9,227 X_{1}+0,697 X_{2}+10,926 X_{3}
$$

\section{REFERENCES}

Funia, M. 2013. "Model Belajar Perubahan Konseptual", (online), (http://mediafunia.blogspot.co.id/2013/01/model-belajar-perubahan-konseptual.html/, diakses 29 Oktober 2017).

Gujarati, D.N. 1995. Basic Econometrics, 3rd edition. New York: MC Graw-Hill International.

Hair, J.F., R.E. Anderso, R.L. Tatham., dan W.C. Black. 1995. Multivariate Data Analysis With Readings, 4th edition. Englewood Cliffs, NJ: Prentice Hall.

Hudojo, Herman. 2003. Pengembangan Kurikulum dan Pembelajaran Matematika. Edisi Revisi. Malang: Fakultas Matematika dan Ilmu Pengetahuan Alam, Universitas Negeri Malang.

Yudistia, Dewi Silvia. 2013. "Model Pembelajaran Perubahan Konseptual”, (online), (https://yudistiadewisilvia.wordpress.com/2013/03/12/model-pembelajaran-perubahankonseptual/, diakses 29 Oktober 2017). 